\title{
Prevalence of Visual Impairment in School Children
}

\author{
Reza Gharebaghi ${ }^{1}$, MD, MPH, FAAO; Fatemeh Heidary ${ }^{1,2}$, MD, MPH, PhD, FAAO, FICO \\ ${ }^{1}$ International Virtual Ophthalmic Research Center (IVORC), Tehran, Iran \\ ${ }^{2}$ Department of Ophthalmology, Faculty of Medicine, Infectious Ophthalmic Research Center, Ahvaz Jundishapur University of \\ Medical Sciences, Ahvaz, Iran \\ ORCID: \\ Reza Gharebaghi: https://orcid.org/0000-0002-4906-8597 \\ Fatemeh Heidary: https://orcid.org/0000-0002-6558-6132
}

J Ophthalmic Vis Res 2020; 15 (1): 123-124

\section{Correspondence to:}

Fatemeh Heidary, MD, MPH, PhD, FAAO, FICO. Department of Ophthalmology, Faculty of Medicine, Infectious Ophthalmic Research Center, Ahvaz Jundishapur University of Medical Sciences, Ahvaz 61357, Iran.

E-mail: drfatemehheidari@yahoo.com

Received: 25-11-2018Ａccepted: 22-01-2019

\begin{tabular}{|l|}
\hline \multicolumn{1}{|c|}{ Access this article online } \\
\hline Website: \\
https://knepublishing.com/index.php/JOVR \\
\hline DOI: \\
10.18502/jovr.v15i1.5968 \\
\hline
\end{tabular}

Dear Editor,

The recent published article by Talebnejad et al sheds light on the prevalence of visual impairments and their associated determinants in school children in Shiraz, south of Iran. ${ }^{[1]}$ We hope this imperative report spurs community action regarding the importance of population-based studies and provides basic information about the targeted prevention programs for children. Of course, the results should be compared with the outcomes of the Iranian State Welfare Organization (ISWO) visual screening programs for children.

We previously published two major studies in this field that derived from the same sample size of the current study but unfortunately were not cited in the recent publication. Firstly, we included 262 eyes of Iranian primary school children in
Shiraz between 6 and 13 years of age and found that intraocular pressure (IOP) and central corneal thickness (CCT) in healthy school children were positively correlated. ${ }^{[2]}$ Secondly, in another published study, we analyzed the relationship between different parameters of Ocular Response Analyzer (ORA) and Corvis ST (CST) in school-aged children in Shiraz, and the relationship between parameters of these two instruments versus the IOP measured by Goldmann applanation tonometer (GAT) was evaluated. We found the highest IOP overestimation by CST and the lowest by cornealcompensated IOP (IOP-CC) compared with GAT. Overall, either low positive correlation or negligible correlation was found among the IOP measurements by three instruments. ${ }^{[3]}$ Furthermore, there are several studies discussing the effect of race on the biometric data of ocular structures. This is an essential issue since recently in a metaanalysis, the authors showed that corneal thickness is thinner in children originating from mixed MalayIndian race than in most other locations. ${ }^{[4]}$ Lastly, a few publications have revealed that age may affect the ocular biometrics. ${ }^{[5]}$ Therefore, we would

This is an open access journal, and articles are distributed under the terms of the Creative Commons Attribution-NonCommercial-ShareAlike 4.0 License, which allows others to remix, tweak, and build upon the work non-commercially, as long as appropriate credit is given and the new creations are licensed under the identical terms.

How to cite this article: Gharebaghi R, Heidary F. Prevalence of Visua Impairment in School Children. J Ophthalmic Vis Res 2020;15:123-124. 
suggest that the authors reiterate all measurements as a cohort analysis since almost five years have passed since the initiation of the study in 2015.

\section{REFERENCES}

1. Talebnejad MR, Nowroozzadeh MH, Mahdaviazad $\mathrm{H}$, Khalili MR, Masoumpour MB, Keshtkar M, et al. The Shiraz Pediatric Eye Study; a population based survey of school age children: rationale, design and baseline characteristics. J Ophthalmic Vis Res 2018;13:293300.

2. Nejabat M, Heidary F, Talebnejad MR, Salouti R, Nowroozzadeh $\mathrm{MH}$, Masoumpour $\mathrm{M}$, et al. Correlation between intraocular pressure and central corneal thickness in Persian children. Ophthalmol Ther 2016;5:235243.

3. Salouti R, Alishiri AA, Gharebaghi R, Naderi M, Jadidi $\mathrm{K}$, Shojaei-Baghini A, et al. Comparison among Ocular Response Analyzer, Corvis ST and Goldmann applanation tonometry in healthy children. Int $\mathrm{J}$ Ophthalmol 2018;11:1330-1336.

4. Farvardin M, Heidary F, Sayehmiri K, Gharebaghi R, Jabbarvand Behrooz M. A Comprehensive meta-analysis on intra ocular pressure and central corneal thickness in healthy children. Iran J Public Health 2017;46:724732.

5. Doughty MJ, Zaman ML. Human corneal thickness and its impact on intraocular pressure measures: a review and meta-analysis approach. Surv Ophthalmol 2000; 44:367408. 